OPEN ACCESS

Approved by:

Annalisa Pastore,

King's College London,

United Kingdom

*Correspondence:

Frontiers Editorial Office

editorial.office@frontiersin.org

Specialty section:

This article was submitted to

Structural Biology,

a section of the journal

Frontiers in Molecular Biosciences

Received: 21 September 2017

Accepted: 21 September 2017

Published: 27 September 2017

Citation:

Frontiers Editorial Office (2017)

Retraction: Structural Basis of the Substrate Specificity and Enzyme Catalysis of a Papaver somniferum

Tyrosine Decarboxylase.

Front. Mol. Biosci. 4:69.

doi: 10.3389/fmolb.2017.00069

\section{Retraction: Structural Basis of the Substrate Specificity and Enzyme Catalysis of a Papaver somniferum Tyrosine Decarboxylase}

\author{
Frontiers Editorial Office* \\ A retraction of the Original Research Article
}

Structural Basis of the Substrate Specificity and Enzyme Catalysis of a Papaver somniferum Tyrosine Decarboxylase

by Guan, H., Song, S., Robinson, H., Liang, J., Ding, H., Li, J., et al. (2017). Front. Mol. Biosci. 4:5. doi: 10.3389/fmolb.2017.00005

The Journal and the authors retract the 9 February 2017 article cited above.

Following article publication, the authors reported that the data upon which the study was based is inconsistent with their own archived data files. Since this discrepancy cannot be resolved by the authors, the authors request that the paper be retracted.

The retraction of the article was approved by the Field Chief Editor of Frontiers in Molecular Biosciences.

Copyright (๑) 2017 Frontiers Editorial Office. This is an open-access article distributed under the terms of the Creative Commons Attribution License (CC BY). The use, distribution or reproduction in other forums is permitted, provided the original author(s) or licensor are credited and that the original publication in this journal is cited, in accordance with accepted academic practice. No use, distribution or reproduction is permitted which does not comply with these terms. 